\title{
Days to Absolute Neutrophil Count greater than 1000 per Microliter
}

National Cancer Institute

\section{Source}

National Cancer Institute. Days to Absolute Neutrophil Count greater than 1000 per

Microliter. NCI Thesaurus. Code C158861.

The number of days to achieve a neutrophil count of greater than 1000 per microliter. 